\title{
Recurrent genital herpes: clinical and virological features in men and women
}

\author{
A MINDEL,* D M COKER, $\dagger$ A FAHERTY, ${ }^{*}$ P WILliAMS* \\ From the *Academic Department of Genitourinary Medicine, Middlesex Hospital Medical School, and the \\ $\dagger$ Department of Genitourinary Medicine, Middlesex Hospital, London
}

SUMMARY One hundred and forty eight patients ( 69 women and 79 men) with often recurring genital herpes were observed for two months. Men had 119 observed recurrences and women 104. The attacks were significantly longer in men than women (8.7 days $v 6.6$ days, $p=0.005)$. Significantly more women complained of symptoms, however, and when symptoms occurred they were more severe. Other significant differences between men and women included age (men were older than women); more men had previously had sexually transmitted diseases; more men had infected a sexual partner, but fewer knew the source of their infection; and men had more lesions at each attack. Positive viral culture results were shown to depend on the amount of erythema, the number of lesions, and the presence of vesicles.

Numbers of patients with genital herpes attending sexually transmitted disease (STD) clinics in the United Kingdom (UK) and the United States of America (USA) have increased dramatically in recent years. ${ }^{1-3}$ Most of these patients have severe first episode genital herpes, but the proportion attending again with recurrent infection has increased significantly. ${ }^{4}$ Although primary attacks last longer and are more severe than recurrences, ${ }^{5}$ it is the recurrent nature of the condition that is responsible for the anxiety and psychosexual dysfunction often seen in these patients. ${ }^{67}$

Despite many reports on genital herpes, only a handful of studies have looked at the clinical features, viral isolation, and likelihood of transmission in patients with recurrent infection, ${ }^{58-12}$ and only small numbers of patients were studied in all but one of these studies. $^{5}$

We undertook the study published here to review the natural history of recurrent herpes, to gather information concerning the source and transmission of the infection, to assess the patients' understanding of the condition, and to compare these features in men and women.

Address for reprints: Dr A Mindel, Academic Department of Genitourinary Medicine, Middlesex Hospital Medical School, James Pringle House, Middlesex Hospital, London W1N 8AA

Accepted for publication 11 June 1987

\section{Patients and methods}

Patients with recurrent genital herpes who had participated in a trial of suppressive acyclovir treatment were entered into the study. All were aged 19 or over and gave a history of at least six attacks of herpes a year. We used a standardised schedule to record the frequency and severity of previous recurrences and treatments, the source of the infection and whether other sexual partners had been infected, and each patient's knowledge about herpes. We observed patients for two months while they received no treatment. During each recurrence patients were asked to return to the clinic, where a history was taken, clinical features noted, and specimens sent to the laboratory for viral culture. Symptoms were graded on a scale of 0 to $3(0=$ none, $1=$ mild, $2=$ moderate, $3=$ severe). Statistical tests used included the $\chi^{2}$ and Mann Whitney U-tests. For ethical reasons homosexual men were not tested for antibodies to human immunodeficiency virus (HIV).

\section{Results}

\section{PATIENT DEMOGRAPHY AND HISTORY OF} PREVIOUS ATTACKS

The study population comprised 69 women and 79 men; 14 of the men were homosexual and the remaining heterosexual. Table 1 shows that the men were significantly older than the women (mean ages $31.8 \mathrm{v}$ 
Table 1 Demographic characteristics and history of attacks in men compared with women with frequently recurring genital herpes. Figures are numbers (percentages) except where otherwise stated.

\begin{tabular}{|c|c|c|c|}
\hline & $\begin{array}{l}\text { Men } \\
(n=79)\end{array}$ & $\begin{array}{l}\text { Women } \\
(n=69)\end{array}$ & p Value \\
\hline $\begin{array}{l}\text { Mean (SD) age (years) } \\
\text { Median (range) duration of attacks (days) } \\
\text { Mean (SD) pain score } \\
\text { Prodrome never experienced } \\
\text { Precipitating factors: }\end{array}$ & $\begin{array}{l}31 \cdot 8(6 \cdot 8) \\
9(3-35) \\
1 \cdot 1(0 \cdot 8) \\
9(12)^{*}\end{array}$ & $\begin{array}{l}29 \cdot 1(6 \cdot 3) \\
7(3-14) \\
1 \cdot 7(0 \cdot 6) \\
10(15)\end{array}$ & $\begin{array}{l}<0.01 \\
<0.001 \\
<0.001 \\
\text { NS }\end{array}$ \\
\hline $\begin{array}{l}\text { Sexual intercourse } \\
\text { Stress }\end{array}$ & $\begin{array}{l}23(29) \\
29(37)\end{array}$ & $\begin{array}{r}9(13) \\
31(45)\end{array}$ & $\begin{array}{l}0.02 \\
\text { NS }\end{array}$ \\
\hline $\begin{array}{l}\text { Previous sexually transmitted diseases (STDs): } \\
\text { Non-specific genital infection } \\
\text { Gonorrhoea } \\
\text { Warts } \\
\text { Syphilis } \\
\text { Any STD }\end{array}$ & $\begin{array}{l}33(42) \\
21(27) \\
8(10) \\
4(5) \\
51(65)^{*}\end{array}$ & $\begin{array}{l}11(16) \\
4(6) \\
13(19) \\
0 \\
27(40) \dagger\end{array}$ & $\begin{array}{l}<0.005 \\
<0.005 \\
\text { NS } \\
\text { NS } \\
<0.01\end{array}$ \\
\hline
\end{tabular}

*data missing in one case.

tdata missing in two cases.

29.1 years, $\mathrm{p}<0.01$ ). The median duration of attacks was significantly longer in men (nine days in men $v$ seven days in women, $\mathrm{p}<0.001$ ), but the mean (SD) pain score was higher in women $(1 \cdot 7(0.57) v 1 \cdot 1(0 \cdot 77)$, $\mathrm{p}<0.001)$. Twenty six women identified menstruation as a precipitating factor, and significantly more men than women thought that attacks were associated with sexual intercourse $(23 v 9, \mathrm{p}=0.02)$.

A history of STDs was more common in men than women. Thirty three men and only 11 women had been treated for non-specific genital infection ( $p<0.005)$ and gonorrhoea had occurred in 21 men and only four women $(p<0.005)$. Similar numbers of men and women had received antiviral treatment in the past, the commonest being acyclovir cream.

Seventy two men had experienced penile lesions, and 58 women had a history of vulval attacks. Other genital and perigenital sites, including the perineum, perianal region, natal cleft, buttock, and anus, were affected in a few patients. Extragenital herpes, predominantly orolabial, was reported by 27 men and 21 women.

\section{SOURCE AND TRANSMISSION}

Table 2 shows that genital herpes was present in the current sexual partner of 15 men and 11 women. The

Table 2 Source of infection and history of transmission comparing men and women with recurrent genital herpes. Figures are numbers (percentages)

\begin{tabular}{llll}
\hline & $\begin{array}{l}\text { Men } \\
(n=79)\end{array}$ & $\begin{array}{l}\text { Women } \\
(n=69)\end{array}$ & $p$ Value \\
\hline Infection in current partner & $15(19)$ & $11(16)^{*}$ & NS \\
Source of infection known & $47(60)$ & $58(84)$ & 0.001 \\
Contact infected by patient & $17(22)$ & $6(9)$ & 0.03 \\
Current partner informed & $56(71)$ & $32(46)$ & 0.02 \\
\hline
\end{tabular}

source of infection was known by 47 men and 58 women $(p=0.001)$. Five of the homosexual men knew the source of infection, compared with 42 of the heterosexual men $(p=0.05)$, but the difference between heterosexual men and women remained significant $(p=0.01)$.

Seventeen men, but only six women, had infected a sexual contact $(p=0.03)$. Fifty six men had informed their current sexual partner of their condition, compared with 32 women $(p=0.02)$.

\section{KNOWLEDGE ABOUT HER PES}

Fifty men and 48 women said that they had received advice about not having sexual intercourse during attacks. Forty one women considered that cervical cytology was necessary yearly, but 24 did not realise the need for cytology at all.

\section{DOCUMENTED ATTACKS}

During the two month observation period, the mean number of attacks was 1.51 in both sexes (range 1-4). The total number of attacks observed was 119 in men and 104 in women. These attacks were confirmed virologically from at least one site in 75 of the attacks in men and in 64 of the attacks in women. The mean time between attacks was 24.7 days in men and 28.5 days in women (not significant). The mean (SD) duration of attacks was 8.7 (5.7) days in men and 6.6 (3.2) days in women $(p=0.005)$.

\section{Symptoms}

Table 3 shows that more women than men complained of local symptoms (pain, itching, or dysuria). For example, pain occurred in 54 attacks in women compared with only 43 in men $(p=0.02)$. The systemic symptoms of headache and malaise were also more common in women; malaise was associated with 52 out of 104 of attacks in women compared with only 
Table 3 Symptoms comparing men with women

\begin{tabular}{|c|c|c|c|c|c|c|}
\hline \multirow[b]{2}{*}{ Symptoms } & \multicolumn{3}{|c|}{$\begin{array}{l}\text { No (\%) of attacks } \\
\text { with symptoms }\end{array}$} & \multicolumn{3}{|c|}{$\begin{array}{l}\text { Mean (SD) symptom score* } \\
\text { in attacks with symptoms }\end{array}$} \\
\hline & $\begin{array}{l}\text { Men } \\
(n=119)\end{array}$ & $\begin{array}{l}\text { Women } \\
(n=104)\end{array}$ & p Value & Men & Women & p Value \\
\hline $\begin{array}{l}\text { Local: } \\
\text { Pain } \\
\text { Itching } \\
\text { Dysuria }\end{array}$ & $\begin{array}{c}43(36) \\
51(43) \\
8(7)\end{array}$ & $\begin{array}{l}54(52) \\
63(61) \\
26(25)\end{array}$ & $\begin{array}{l}0.02 \\
0.008 \\
0.002\end{array}$ & $\begin{array}{l}1.4(0.6) \\
1.5(0.7) \\
1.1(0.4)\end{array}$ & $\begin{array}{l}1.6(0.7) \\
1.8(0.8) \\
1.5(0.8)\end{array}$ & $\begin{array}{l}0.04 \\
0.04 \\
\text { NS }\end{array}$ \\
\hline $\begin{array}{l}\text { Systemic: } \\
\text { Fever } \\
\text { Headache } \\
\text { Malaise }\end{array}$ & $\begin{array}{l}18(15) \\
15(13) \\
41(35)\end{array}$ & $\begin{array}{r}9(9) \\
24(23) \\
52(50)\end{array}$ & $\begin{array}{l}\text { NS } \\
0.04 \\
0.02\end{array}$ & $\begin{array}{l}1.2(0.5) \\
1.1(0.5) \\
1.2(0.4)\end{array}$ & $\begin{array}{l}1.0(0.0) \\
1.3(0.4) \\
1 \cdot 1(0.4)\end{array}$ & $\begin{array}{l}\text { NS } \\
\text { NS } \\
\text { NS }\end{array}$ \\
\hline
\end{tabular}

*Symptoms graded 0 (none), 1 (mild), 2 (moderate), or 3 (severe).

41 out of 119 in men $(p=0.02)$. In those who had symptoms, the mean symptom scores for pain and itching were significantly higher in the women $(\mathrm{p}=0.04)$.

\section{Signs and virology}

One hundred and one attacks in men affected the penis, and 69 attacks in women affected the vulva. Less common sites were the natal cleft, perianal region, suprapubic area, buttock, perineum, and cervix. Two sites were simultaneously affected in four attacks in men and 10 attacks in women. Three or more sites were affected in one attack in only one man.

The mean (SD) number of lesions in men was greater than in women $(2.9(2.41) \vee 2.0(1.20))$, $\mathrm{p}=0.001$. The number of lesions correlated significantly with a positive viral culture result ( $p<0.001$ ), but positive culture results did not depend on the anatomical site of the lesion.

Inguinal lymphadenopathy was present in 27 attacks in men and 29 attacks in women, and as many patients with as without enlarged lymph nodes had positive viral culture results. The degree of erythema (graded $0-3$ ) correlated significantly with a positive viral culture result $(p=0.04)$, as did the presence of vesicles $(p=0.001)$. Even at the crusting stage five of 14 lesions yielded positive culture results.

\section{Discussion}

This study showed that significantly more women with recurrent herpes suffer from pain, itching, dysuria, headache, and malaise than their male counterparts, and that these symptoms tended to be more severe. As a third of women reported that their attacks were associated with menstruation, some of the symptoms in women could be related to premenstrual and menstrual factors. It is of interest, however, that men had significantly longer attacks than women. HIV infection could be a possible reason for the longer duration of symptoms in men, though this was unlikely to be important in this study as only 14 of the men were homosexual and only a quarter of homosexual men attending this clinic are known to be HIV positive..$^{13}$ The differences in symptomatology between men and women are similar to those reported by Corey and colleagues from Seattle. ${ }^{5}$

In this study more women than men knew the source of their infection, but fewer had infected a contact or informed their current sexual partner of their condition. These findings suggest that the women were more careful in the way that they conducted their sexual relationships, but were less open about their condition, perhaps reflecting a fear that disclosure would receive an unsympathetic response from the partner. A surprising feature of this study was the large number of patients who claimed that they had not received advice about abstaining from sexual intercourse during attacks or about the need for cervical cytology. The need to reinforce information to all patients is apparent, particularly to men about transmission and to women about cytology and about risks to neonates.

Men had significantly more lesions at each attack than women. These findings are similar to those of Corey et $\mathrm{al}^{5}$, though they reported more lesions per episode ( 7.5 for men, 4.8 for women) than we found. Our findings in this respect agree more closely with those of Guinan et al, who found that $78 \%$ of women had only a single lesion at each recurrence. ${ }^{.1}$

Positive viral culture results were shown to depend on the amount of erythema, the number of lesions, and the presence of vesicles. Other studies have confirmed that the optimum time for taking samples for herpes culture is at the early stages of recurrence, when erythema is at its maximum and vesicles are still present. ${ }^{511}$ Even at the crusting stage, however, $36 \%$ of lesions in our study were culture positive. This suggests that even when crusts are present a viral culture may still be worthwhile and, as such lesions are potentially infectious, patients should be advised to refrain from sexual intercourse until healing is complete. The infection can also be transmitted when 
patients are asymptomatic, ${ }^{14}$ but this issue was not addressed in our study.

In summary, we have identified the following differences between men and women; women get worse symptoms, but men have longer duration of attacks and more lesions at each attack. Men were more conscious of attacks being provoked by sexual activity, and had previously had a sexually transmitted disease. More women knew the source of their infection, but fewer told or infected a new sexual partner. These factors may be important when diagnosing, treating, and counselling patients with herpes.

\section{References}

1 Communicable Disease Surveillance Centre. Sexually transmitted disease surveillance in Britain-1984. Br Med J 1986;293:942-3.

2 Becker TM, Blount JH, Guinan ME. Genital herpes infections in private practice in the United States, 1966-1981. JAMA 1985;253:1601-3.

3 Anonymous. Genital herpes infections, United States, 1966-1979. MMWR 1982;31:137-9.

4 Hindley DJ, Adler MW. Genital herpes: an increasing problem? Genitourin Med 1985;61:56-8.

5 Corey L, Adams HG, Brown ZA, Holmes KK. Genital herpes simplex virus infections: clinical manifestations, course and complications. Ann Intern Med 1983;98:958-72.

6 Marne S, Sandler I. Coping and adjustment to genital herpes. J Behav Med 1984;7:391-409.

7 Goldmeier D, Johnson A, Jeffries D, et al. Psychological aspects of recurrences of genital herpes. J Psychosom Res 1986;30:601-8.

8 Kaufman RH, Gardner HL, Rawls WE, Dixon RE, Young RL. Clinical features of herpes genitalis. Cancer Res 1973;33:144651.

9 Kawana T, Kawagoe K, Takizawa K, Chen JT, Kawaguchi T, Sakamoto S. Clinical and virologic studies on female genital herpes. Obstet Gynecol 1982;60:315-9.

10 Reeves WC, Corey L, Adams HG, Vontver LA, Holmes KK. Risk of recurrence after first episodes of genital herpes. $N$ Engl J Med 1981;305:315-9.

11 Guinan ME, MacCalman J, Kern ER, Overall JC, Spruance SL. The course of untreated recurrent genital herpes simplex infection in 27 women. $N$ Engl J Med 1981;304:759-63.

12 Brown ZA, Kern ER, Spruance SL, Overall JC. Clinical and virologic course of herpes simplex genitalis. West $\mathrm{J}$ Med 1979;130:414-21.

13 Carne CA, Weller IVD, Johnson AM, et al. Prevalence of antibodies to human immunodeficiency virus, gonorrhoea rates and changed sexual behaviour in homosexual men in London. Lancet 1987; i:656-8.

14 Mertz GJ, Schmidt O, Jourden JL, et al. Frequency of acquisition of first-episode genital infection with herpes simplex virus from symptomatic and asymptomatic source contacts. Sex Transm Dis 1984;12:33-9. 